\title{
Case hacks: Four hacks for promoting critical thinking in case-based management education for sustainable development
}

\author{
Thomas Taro Lennerfors ${ }^{\mathrm{a}}$, Per Fors ${ }^{\mathrm{a}}$, and Jonathan R. Woodward ${ }^{\mathrm{b}}$ \\ ${ }^{\mathrm{a}}$ Uppsala University; ${ }^{\mathrm{b}}$ University of Tokyo
}

\begin{abstract}
In management education at engineering and business schools, the case-based method is commonly used. The case-based method has a strong action orientation but is seen to downplay critical thinking, which is an important component in Education for Sustainable Development (ESD). Current literature suggests two ways in which the case-based method can be improved, namely by producing better cases, and by improving classroom practice. This paper contributes to research and practice on case-based ESD within management education by outlining a third way: hacking cases, in other words, making modifications to existing cases to promote critical thinking. The hacks presented in this paper are based on a review of previous empirical and conceptual research about, and, on our own experiences of critical thinking. They are: (I) exploring synergies and conflicts; (2) expanding empirical knowledge; (3) shifting perspective; and (4) creating spaces for dialogue. By employing the hacks, case-based management ESD can be adapted to promote both action and critical thinking and, thereby, become an improved educational method in management ESD. An illustration of these four hacks within the course Managing sustainability in global industrial companies is provided.
\end{abstract}

Keywords: Education for Sustainable Development (ESD), case-based learning, management education, critical thinking, hacks

\section{INTRODUCTION}

It is generally assumed that through "teaching and learning the proper solutions, desirable attitudes, correct behavior, necessary competences, etc." (Van Poeck \& Östman, 2017, p. I406), various challenges related to sustainable development are possible to overcome. Such education is termed Education for Sustainable Development (ESD), and is described by UNESCO (2012) as focused on promoting sustainable behaviors and teaching skills related to making sustainable decisions in the future professional life of the students.

The responsibility for sustainable development lies with everyone. However, decision makers in private, for-profit companies exert a significant impact on the economy, society, and environment. Therefore, it is pivotal that students who will take on managerial positions in such companies are educated to manage, or indeed care about, aspects related not only to the profitability of the company but also to social and environmental sustainability. Given that the case-based method, in this paper understood as using ready-made case narratives produced by institutions

*Correspondence to: Thomas Taro Lennerfors, lennerfors@gmail.com 
such as Harvard Business School ${ }^{\mathrm{r}}$, is often used at both technical (faculties at) universities and business schools where management is usually taught, our interest lies in exploring how the case-based method can be used to educate for sustainability. We are aware that a case can also be a brief background to a problem, a news article, or a video (cf. Sprain \& Timpson, 20I2; Rippin, Booth, Bowie, \& Jordan, 2002), but given that the use of ready-made case narratives is widespread in management education, the aim of the paper is to discuss this form.

In this understanding of the case-based method, students are presented with well-crafted cases often containing unique, authentic insights into the companies portrayed. These case narratives often lead up to a critical point where action is required. The students then put themselves in the shoes of the protagonist manager and try to think out the best action. In this method, students are encouraged to practice problem-solving and decision-making, and to make solid arguments for their decisions in relation to the narrative provided in the case (MacLellan, 20I8). The casebased method includes the important dimension of action orientation sought after in ESD (cf. UNESCO, 20I2). However, the case-based method is sometimes held to be uncritical and perhaps too action-oriented as the method is often used to train future managers to make quick decisions based on available information (Schmitt Figueiró \& Raufflet, 20I5; Bridgman et al., 20I6, Chetkovich \& Kirp, 200I; Collinson \& Tourish, 20I5; Liang \& Wang, 2004). This can prove problematic from the viewpoint of ESD, where critical thinking is often seen as a crucial component for reasons explained in the following paragraph (Hasslöf \& Malmberg, 20I5; Siller, 200I; Thomas, 2009; Wals \& Jickling, 2002).

Although there is a common perception (also advanced by UNESCO and the UN, among others) that sustainable development is development where there is harmony between the three sustainability dimensions (i.e. economic, social and environmental), researchers generally conclude that there are conflicts within and among these three dimensions, as well as between the Sustainable Development Goals (SDGs). For example, the goal of increased economic growth is in conflict with many of the targets aiming to protect the planet from degradation (Hickel, 2019), and technological development and environmental sustainability could conflict as well (Hornborg, 200I; Knutsson, 20I8; Lennerfors, Fors, \& van Rooijen, 20I5; Fors, 20I9; Lennerfors, 2019). Furthermore, Wals and Jickling (2002) expose conflicts between holistic conceptions of sustainability and more specific or instrumental significations, and between words, meanings, values and practices related to sustainability, and argue that the idea of sustainability as an overall aim for societal development is "conceptually flawed" since it provides no guidance on how to deal with "contesting claims between advocates of incompatible values systems" (p. 222). In line with earlier research we find highlighting such conflicts conducive for ESD, since they also empower and give agency to students and educators to make sense of and create their own meaning for the concept (Hasslöf \& Malmberg, 20I5). Indeed, according to Wals and Jickling (2002), "universities should develop in their students the competencies which will enable them to cope with uncertainty, poorly defined situations and conflicting or at least diverging norms, values, interests and reality constructions" (p. 224). To understand and navigate the contested domain of sustainability, critical thinking is necessary.

Within existing literature on the case-based method within management education, two ways are outlined for how to facilitate critical thinking: namely, to write more nuanced case narratives (Bridgman, 20IO; Diochon, Raufflet, \& Mills, 2013; Raufflet \& Mills, 2009; Sauerbronn,

\footnotetext{
${ }^{1}$ https://hbsp.harvard.edu/cases/
} 
Diochon, Raufflet, \& Mills, 20I8) and to facilitate critical thinking in the classroom (Currie $\&$ Tempest, 2008; Rippin, Booth, Bowie, \& Jordan, 2010). However, it has been argued that the way cases are reflecting institutional settings, more specifically those of for-profit, predominantly managerialist educational institutions, can be a hindrance to writing more nuanced case narratives conducive to critical thinking (Bridgman et al., 2016; Contardo \& Wensley, 2004; Podolny, 2009), and even though there are new developments in producing better cases, also highlighting the negative effects of managerial practice (Diochon et al., 20I3; Raufflet \& Mills, 2009; Sauerbronn et al., 2018), it is unlikely that there will ever be any case that is sufficient in itself to promote critical thinking. We also argue that although it is important to facilitate critical thinking in the classroom (Currie \& Tempest, 2008; Rippin et al., 20IO), this not only poses demands for individual teachers; critical thinking should also be part of a process, in which students are working on cases before class.

Therefore, we suggest a third way forward, namely to provide case hacks. We draw on the currently popular trend of hacks, where hack according to Merriam-Webster Online Dictionary ${ }^{2}$ means "a clever tip or technique for doing or improving something". In the context of cases, hacks are ways to supplement existing cases with additional perspectives, materials, and instructions that encourage the students to think critically while working on a case. In this paper we come up with four hacks based on conceptual and empirical research on critical thinking within ESD and our own experiences in developing and teaching the course Managing sustainability in global industrial companies. The course, which has been offered by the authors in 2016, 2018, 2019, and 2020, addresses a diverse set of students from mainly industrial management but also other disciplines and different nationalities based at Uppsala University and the University of Tokyo. We call these four hacks: (I) exploring synergies and conflicts; (2) expanding empirical knowledge; (3) shifting perspective; and (4) creating spaces for dialogue.

In the following sections of the paper we will describe the case-based method, the critique against it, and develop four case hacks that can be used in order to promote critical thinking among students while maintaining the action-orientation of the method.

\section{CASE-BASED MANAGEMENT EDUCATION FOR SUSTAINABILITY}

Management education is basically the academic discipline in which students both learn about management and train themselves for a future career as managers and industrial leaders. As many contemporary companies now strive not only to increase their profits but have also recognized their central role in and responsibility for achieving a more sustainable society, management educators have urged for a transformation of management education (Audebrand, 20I0). While we certainly welcome this urge to transform management education - to "radically rethink management education" (Figueiró \& Raufflet, 20I5, p. 27) even - many courses and programs still look more or less the same, but with more courses in, for example, business ethics and sustainability management. Also, the case-based method has been identified as the most commonly-used technique to teach students about such issues.

However, the case-based method is by no means new within disciplines such as management and business education. This method emerged in the late nineteenth century and has since then remained an important mode of management education (Rippin et al., 2002). Historically, there was a wider interpretation of what a "case" could be, but in recent years, according to

\footnotetext{
${ }^{2} \mathrm{http}: / /$ merriam-webster.com
} 


\section{Thomas Taro Lennerfors et al.}

Rippin et al. (2002, p. 432), a case is normally a "written narrative which usually contains some financial or numerical data". Such cases are often used to develop professional business skills in a realistic but largely simulated environment, where students are required to analyze a situation and propose a course of action (Giraudou, Lennerfors, \& Woodward, 2018). The case-based method usually asks students to imagine themselves in the role of the protagonist of the case (MacLellan, 20I8), usually a CEO or - when it comes to sustainability - a sustainability manager, and to make decisions based on solid arguments.

The case-based method has been subjected to criticism from a range of different perspectives, alongside suggestions for how to improve the method. One predominant critique is that the case study is managerialist, decision-forcing, and instrumental, and does not promote a broad, critical perspective (Bridgman et al., 20I6). Bridgman et al. (2016) show how these particularities of the case-based method have been shaped in conjunction with the history of the Harvard Business School. The authors, however, show that there was an alternative development path in the I920s and I930s that included the labor union's perspectives in the case-based method, but this was discontinued. Bridgman et al. (2016) claim that case-based education should be revitalized by scrutinizing labor relations, by using cases as an opportunity to think about how we think, and to avoid the narrowing tendencies of decision-forcing by broadening the perspective.

Furthermore, the case-based method has been criticized for constructing individualized, heroic portrayals of leadership (Collinson \& Tourish, 2015; Chetkovich \& Kirp, 200I; Liang \& Wang, 2004). In a thorough analysis of the best-selling cases in public policy, Chetkovich and Kirp (200I) find that the narrative in such cases is more often than not about a high-level, lone protagonist who alone makes important decisions, eschewing collaborative decision-making. They also manage to show that street-level actors are not of importance and that the context matters little. Collinson and Tourish (2015) propose that we should rethink the case-study method, by critiquing the romanticization of leaders, exposing power struggles, and emphasising the role of followership. Bridgman (2010) also describes the individualizing tendency of the case-based method, focusing on the moral dilemmas of an individual manager rather than taking the structural features of capitalism and the role of government into account. He argues that a way forward is to write better cases, and throws light on the growing number of "dark side cases" focusing on the downsides of business and management (Diochon et al., 2013; Raufflet $\&$ Mills, 2009; Sauerbronn et al., 2018). Podolny (2009) puts forward a similar critique, arguing that while cases can be a source of interdisciplinary integration they rarely are, because the faculty members who write cases are often from the same discipline and, therefore, cases becomes function-specific and not holistic. The narrowness of cases has been held to be a consequence of the managerialist, for-profit, institutional setting in which they are produced (Bridgman et al., 20I6; Contardo \& Wensley, 2004).

Mintzberg (2004) critiques the case-based method for being too abstract, which exposes the underlying assumptions of management as formulating a policy rather than facilitating it, and on instilling the habit of quick, unreflected decision-making among management students. Rather, Mintzberg claims, managers should be trained to sense things, to weave their way through complex phenomena, and to probe deeply. Chia (2005) concurs that the case-based method is helpful for well-defined problem-solving, but the more urgent problem facing the practicing manager is how to frame and define the "case" in the first place.

Business cases are also critiqued for their bias. Women protagonists are either absent in most of the case studies or portrayed as less visionary, risk-taking and agentic than men (Sharen \& 
McGowan, 2019). Furthermore, Contardo and Wensley (2004) argue that the Harvard cases implicitly embed values of managerialism and American capitalism. Starkey and Tiratsoo (2007), discussed in Starkey and Tempest (2009), show that the best-selling cases tend to present just the voices of senior managers and other managers rather than employees, customers, and other stakeholder groups.

A similar critique of the case-based method exists within management ESD, where the casebased method often fails to promote any deeper understanding of sustainability-related problems (Montiel, Antolin-Lopez, \& Gallo, 2018; Mesny, 20I3; Figueiró \& Raufflet, 20I5). Reficco and Jaén (2015), for example, show how case narratives and questions need to be adjusted to promote sustainability thinking, but argue that how this should be done in practice is insufficiently researched. Likewise, in management ESD, the case-based method is critiqued for its individualism, thus not promoting systemic but rather instrumental understanding of sustainability challenges (Figueiró \& Raufflet, 2015).

In the early 2000s, Rippin et al. (2002) saw great promise in reforming the case-based method to promote critical thinking. The authors argued that for the past 20 years the ways in which educators use business cases had evolved from challenging students to find the one, most reasonable solution to a case problem, to emphasizing critical thinking and skills associated more with liberal arts education. This was due to several reasons. First, organizations started to be seen as more complex which meant that one should not assume that there is any single most effective solution or best practice. Second, business education started to be reevaluated and has shifted from being about business, rather than just for business. We argue that this has also become accentuated with the trends of bringing in aspects of Corporate Social Responsibility (CSR), sustainability and business ethics, which further complicates the role of the organization. However, writing almost 20 years later, some of the promises are yet to be fulfilled.

While many researchers are critical of the case-based method, there are mainly two suggestions given in such research on how to improve case-based education. The first and most predominant suggestion to change case-based education is to simply produce better cases that promote critical thinking (Diochon et al., 2013; Raufflet \& Mills, 2009; Sauerbronn et al., 20I8). However, while this is indeed one solution to much of the criticism presented above, we expect that very few educators have the time, competence and insight into a specific company to be able to produce completely new cases. The second suggestion is to use skilled and reflective educators who through classroom discussion facilitate dialogue in order to promote critical thinking. For example, Currie and Tempest (2008), in line with Rippin et al. (2002), suggest that educators should aim to uncover the voices of marginalized stakeholders, invite discussion about the political and emotional realities of the case-study organization as experienced by employees, and give voice to students' experiences of organizations. They illustrate that a teaching case when used by a reflective management teacher "prepared to facilitate rather than impose their expertise and provide answers, can develop critical and reflective abilities, and independence of thought" (Currie \& Tempest, 2008, p. 48). However, in the paper by Currie and Tempest (2008), the teacher had in fact also developed his own cases, which might imply that this is more challenging with existing cases. Furthermore, to rely on classroom practice means that the critical reflection comes when discussing the case in class rather than promoting critical thinking when the students are working on the case on their own.

As proposed in the introduction, we suggest a third way forward: to hack existing cases. By this term we mean that we as educators can add additional, complementary, critical, or destabilizing educational material, perspectives, and instructions, which are provided to the student at the 


\section{Thomas Taro Lennerfors et al.}

same time as the case is given. This approach does not require the re-writing of case narratives or descriptions, and it also problematizes the hope for "the perfect case" which includes all possible perspectives, stakeholders, and standpoints. Even the cases that stem from the "dark side" tradition (Diochon et al., 2013; Raufflet \& Mills, 2009; Sauerbronn et al., 2018), where the negative sides of business and management are highlighted, would perhaps need some hacking. The method that we propose also allows for some generalizability since it is not as dependent upon the critical, reflective classroom skills of the teacher (cf. Currie \& Tempest, 2008).

Our hacks are based on an ambition to promote critical thinking, both when students work individually or in groups with cases, and in teacher-led seminars. The concept of critical thinking, alongside our proposed case hacks, will be outlined in the following section of the paper.

\section{TOWARDS THE FOUR HACKS FOR CRITICAL THINKING WITHIN MANAGEMENT ESD}

Critical thinking is today increasingly referred to as a key competence or a highly valued set of skills for the $2 \mathrm{I}^{\mathrm{st}}$ century, not least within ESD (Holfelder, 2019; Komasinski \& Ishimura, 20I7; Miller \& West, 20I8; Thomas, 2009). Straková and Cimermanová (2018) see the promotion of critical thinking as a necessary step towards sustainability transformation in higher education, and Zoller (20I5), among others, sees critical thinking as a crucial component in the broader concept of "sustainability thinking".

Many researchers suggest that critical thinking is a process that requires a wide range of skills rather than a skill in and of itself. These skills range from the ability to identify one's own and others' positions and arguments, to evaluate arguments and methods, to identify and question underlying assumptions, to reflect in a structured way, to draw conclusions, and more (Cottrell, 20I7). It is often assumed that critical thinking requires evaluation, judgment and logical reasoning skills to tell the "reasonable" from the "unreasonable" (Nilson, 20II). Critical thinking is sometimes used synonymously with phronesis or practical wisdom, i.e. the competence of knowing what competencies and principles should be applied in a particular situation and how (cf. Komasinski \& Ishimura, 20I7). For the educator, teaching critical thinking means to teach how to think, rather than what to think (Mulnix, 20I2).

Despite the importance given to critical thinking and the availability of definitions, it is difficult to pinpoint exactly what critical thinking is. Indeed, Hasslöf and Malmberg (2015) found in a study on critical thinking among ESD educators that critical thinking was identified as a core concept, but that no shared meaning of the term could be found (see also Komasinski \& Ishimura, 20I7; Wals \& Jickling, 2002; Thomas, 2009). Furthermore, Haigh (2016) argues that while critical thinking has become a sort of mantra for higher education in the $2 \mathrm{I}^{\mathrm{st}}$ century, little attention is paid to encourage students to think critically and search for deeper understanding. In this paper, we do not aim to develop yet another definition of what critical thinking within ESD is, but instead aim to draw on existing research on critical thinking in ESD to explain what kind of thinking our hacks aim to facilitate.

First of all, a central component of critical thinking is the ability to see and take into consideration synergies and conflicts when solving problems and making decisions. Above, we referred to the work of Wals and Jickling (2002) and Hickel (2019), who argue that there could be both synergies and conflicts between different sustainability goals. Educators should therefore train students to make sense of conflicting values and outcomes, and to make decisions based on that. While technological progress and economic growth can sometimes be desirable from a sustainability perspective, this relation is not always synergistic. To highlight synergies, but also 
conflicts, is vital in order to be able to problematize predefined unsustainable discourses as well as predefined sustainable discourses, such as sustainable development, sustainable growth and green-tech (Hasslöf \& Malmberg, 2015). Therefore, a first important aim for educators would be to assist students conceptually in exploring synergies and conflicts within the theory and practice of sustainability. This translates into our first hack: exploring synergies and conflicts.

Second of all, critical thinking cannot be detached from knowledge about a particular empirical field. According to Bailin, Case, Coombs, \& Daniels (1999), critical thinking requires domain-specific knowledge, referring to knowledge about the empirical domain where the (sustainability) challenge is located. This points towards the importance of looking beyond the description of the sustainability challenge in order to achieve a deeper understanding of the context of the challenge. Furthermore, expansion of empirical knowledge promotes new and more creative ways of imagining future sustainable business strategies that are not constrained by, for example, values, worldviews and assumptions inherent in the case description. This implies that a second important aspect for an educator is to expand empirical knowledge about the problem beyond what is given in the problem formulation. This translates into our second hack: expanding empirical knowledge.

Third, as emphasized by Price and Hatcher (2008), the perception of what constitutes the problem is very much dependent on the narrow perspective of a single problem owner in many case narratives. However, in line with Komasinski and Ishimura (2017), we argue that students need to be confronted with the views and perspectives of other stakeholders. Thus, critical thinking requires one to take a "step back" and be "detached" (Onuki \& Mino, 2009), to "see the bigger picture" (Mason, 2007), and to see the perspectives of different stakeholders (Komasinski \& Ishimura, 20I7). Furthermore, it is important to slightly shift the perspective by taking the perspective of a competing company, or a company or organization in the same industry. By doing this, we draw on the idea of critical thinking as "a catalyst for interpreting, imagining and potentially re-narrativizing the past, present, and future" (Miller \& West, 2018). By re-narrativizing the case from a slightly different perspective, students can nuance the perspective given in the case study. A third aim for a sustainability educator is thus to include the perspectives of different stakeholders and take into account their worldviews and motives. This translates into our third hack: shifting perspective.

Fourth, critical thinking is performed and nurtured in a social setting, where an inclusive process is perhaps as important as the outcome (Holfelder, 2019). According to Paul and Elder (2007), some aspects of critical thinking can be traced back to the Socratic method where it refers to the dialogue between student and teacher aiming to achieve new and improved understanding about a topic or concept. Komasinski and Ishimura (2017) argue that critical thinking is promoted in a social setting where students get to articulate their own views and understanding and comment on others'. Such thinking occurs not only in teacher-led seminars, but also more importantly in discussions within groups when working with problems, or in dialogues with different stakeholders of a particular sustainability-related problem. Paul (I98I) suggests that dialogue with others who are different is essential to critical thinking, not least with people who have different worldviews or cultural backgrounds. In line with Osberg and Biesta (20I0) and Hasslöf and Malmberg (2015), we argue that educators must create spaces where it is possible to collaboratively think critically about assumptions and norms, and where students are able to discuss standpoints, values and options (i.e. to practice critical thinking). Thus, an important aim for the educator is to nurture these spaces for collaboration and discussion. This translates into our fourth hack: creating spaces for dialogue. 
In the following part, we will flesh out our four hacks and illustrate them with examples from the course Managing sustainability in global industrial companies.

\section{FOUR HACKS FOR CRITICAL THINKING IN PRACTICE}

In this part we aim to describe how we work with cases in the course Managing sustainability in global industrial companies, and how our proposed hacks have been implemented and used throughout the course. The students in this course are provided with off-the-shelf case narratives, while the hacks are provided as a separate document. These hacks, as mentioned above, aim to promote critical thinking by encouraging the students to explore potential synergies and conflicting values and, to give additional information about the case and the context, to shift the perspective from the managers to other stakeholders, and to encourage working together instead of individually with the case. Each of the sections below starts off by describing a particular hack, followed by an illustration of how the hack has been implemented in a case.

\section{Exploring synergies and conflicts}

We encourage educators to provide materials, perspectives, and instructions that allow students to explore synergies and conflicts within sustainability. Although synergies are, not surprisingly, more desirable but also possible to achieve, conflicts are not a sign that sustainability is "conceptually flawed" (Maniates, 2017). Rather, we agree with Wals and Jickling (2002), who see that conflicts within the sustainability concept are productive and can enhance students' grasp of the various issues and perspectives at stake.

In the beginning of the course, the students are given three different perspectives on the concept of Creating Shared Value (CSV). In Kramer and Porter's (20II) influential article, which argues that by addressing social and environmental issues we can create economic value, thus leading to a win-win-win scenario. However, since that article focuses almost solely on synergies, the students also read Crane, Palazzo, Spence, \& Matten (2014), which is a critique of CSV, arguing that this assumption is naïve and that the concept does not take into consideration the various value conflicts at stake in the operation of a for-profit company. We hold that the point of the article is to destabilize the synergetic conception, and also to be open to seeing conflicts within and between economic, social, and environmental sustainability. The third contribution to the first week's input is the documentary The Corporation (Achbar, Simpson, Achbar, \& Abbott, 2003), which argues that corporations are institutionally myopic and self-centered, therefore being unable to take social and environmental issues into account. This theoretical view implies that sustainability (other than economic) in the corporate realm is impossible, and that there can be nothing other than conflicts between economic sustainability on the one hand and social and environmental sustainability on the other. These three perspectives all address the role of business for a sustainable society, but with radically different angles and conclusions. We take the synergies and conflicts between different sustainability dimensions (most notably economic profit vs. social and environmental value) as a key theoretical tool for analyzing the cases in the course.

For example, the first case narrative in the course is about how Nike (Paine et al., 2013) went from a reactive approach to social issues to the current situation where they synergistically embrace social and environmental sustainability as an innovation strategy manifested by the shoe Nike Flyknit, which has an almost waste-free production process and which is also highly appreciated by athletes. The case is thus written in line with the theoretical perspective of shared value. However, by providing our hack - namely, instructions to link the case to not only shared value but also less synergistic accounts of sustainability - many students reached the conclusion 
that although the corporate discourse was about shared value and win-win-win scenarios, there were also conflicts, for example, between economic profits and increasing labor standards in contract factories, and between economic sustainability and tax compliance.

\section{Expanding empirical knowledge}

To avoid premature problem-solving and action orientation, the students should be either provided with or urged to actively search for additional empirical knowledge beyond that given in the case in order to reach a deeper understanding. By gaining domain-specific knowledge (Bailin et al., 1999), i.e. knowledge about the empirical domain where the sustainability challenge is located, critical thinking can be promoted.

Through our hack - namely, additional material, or instructions to look for additional material - we encourage the students to go beyond the case description to find a solution to the case questions, or indeed to problematize the framing of the case. In the Nike case (Paine et al., 20I3), some students decided to draw on the Paradise Papers - a global investigation that unveiled the offshore activities of powerful people and corporations - to enhance their analysis. Nike is also one of the companies mentioned in the critical documentary The Corporation, so this could also count as a source of empirical information to enhance the analysis of the case. However, what we would like to discuss here is more closely related to the second case in the course, namely, how Intel has managed the issue of conflict minerals (Hoffman, 20I5).

Apart from studying the case material about Intel, the students were encouraged to read up on conflict minerals and the political situation in central Africa, in particular the Democratic Republic of Congo (DRC) from where some of the minerals are sourced. The students also were instructed to watch the critical documentary about conflict minerals, Conflicted - The Fight over Congo's Minerals, ${ }^{3}$ which exposed new empirical knowledge showing how systems that aim at promoting traceability constantly suffer from corruption, and that we cannot be sure whether products labeled as "conflict-free" are indeed free of conflict minerals. This jolts the description given in the case study and forces the students to understand that even within the empirical domain there are differing views and perspectives to take into account.

\section{Shifting perspective}

Through instructions, we urged students to not only focus on the central stakeholder(s), but by shifting perspective to also look at the problem from other stakeholders' perspectives. Furthermore, since case narratives often revolve around the success story of one company, we particularly encourage the students to take the perspective of another company or organization that works in the same context and faces the same challenges to see how they solved or discursively accounted for it. By comparing with other companies, the student can problematize and nuance any allegedly successful solution to a sustainability-related challenge.

In the Royal Caribbean case (Quelch \& Rodriguez, 20I4), students, in line with the previous hack, expand empirical knowledge by reading through the sustainability reports of Royal Caribbean. In the reports it is highlighted how the cruise company has harmonious relationships with the local communities on the island where they operate, for example, contributing to the local economy by creating jobs. In order to shift perspective, we conducted interviews with two representatives of islands where cruise companies were establishing their operations and provided

\footnotetext{
${ }^{3}$ https://www.youtube.com/watch? $\mathrm{v}=27 \mathrm{BZgQ} 5 \ln 0 \mathrm{w} \& \mathrm{t}=13 \mathrm{~s}$
} 
this material to the students. On one Japanese island, the inhabitants had organized a protest against the plans of one cruise company which temporarily postponed its establishment. On a Swedish island, the respondent said that he/she was surprised that all the local stakeholders were in favor of establishment despite the negative environmental and social consequences these cruise companies were expected to have on the island. The inclusion of these perspectives often gave rise to questions other than those provided in the case description.

To take other stakeholders' views into account is the core of this strategy, but we more specifically encourage students to shift their perspective slightly by taking the perspective of a similar company and organization. Most case descriptions (and all cases that are explored throughout the course) are written from the point of view of one particular corporation. In the Intel case, for example, students were instructed to investigate similar companies within the same sector. They found that although Intel was described as a sustainability champion in the case narrative, companies such as AMD, Fairphone and Apple approached the challenge similarly. They also learned that some Japanese companies were not communicating their sustainability strategies as aggressively as Intel. In the Royal Caribbean case, Royal Caribbean was described as superior to, for example, Carnival Cruises in terms of health, safety and environmental efforts. A central question of the case was whether they should use this superiority in their marketing strategy by branding themselves as "a sustainable cruise company". The students were encouraged to go beyond the information given in the case and compare with the sustainability data produced by Carnival Cruises. After such an analysis they realized that it is far from straightforward which of the companies is more sustainable from a social and environmental perspective, since the data is not uniform, standardized and comparable. Given this conclusion, students started to question the whole framing of the case, since it implied that Royal Caribbean is a more sustainable company than Carnival Cruises. By making the students compare the focal company with other companies in the same industry, they can problematize and nuance any success stories of the focal company in these cases. Incidentally, students often come to realize that sustainability reports are selective and aimed more at creating a good impression of the company than anything else.

\section{Creating spaces for dialogue}

Critical thinking can be enhanced by collaboration and dialogue, for example, among students, with the teacher, and by interacting with relevant stakeholders. When students are instructed to work together on and discuss the aspects of each case, they need to constantly negotiate their standpoints, perspectives and worldviews, and they can enter into a dialogue which contributes to critical thinking.

In the course, rather than working on a case alone, the students are instructed to collaborate across disciplines and countries. In a case group, they contribute with different perspectives and, not least, different access to the local contexts (Sweden and Japan). Given the international student base in both countries, they also have access to additional countries' news media covering the issue of interest. For example, when regarding conflict minerals different group members often research how the issue of conflict minerals is perceived in their local country. Some Japanbased students realized that the issue is not discussed as much among students as in Sweden, which also leads to increased understanding and sometimes a willingness to create change for sustainability in their local context. Also, given that the students in the course originate from many different countries, there have been students from central Africa who can discuss the conflict mineral case study from their lived experience. While some assignments are suitable to work with individually, many of the assignments in the case study are designed to promote 
collaboration and dialogue. For example, in the Intel case the group members can work individually to I) assess Intel's current and past sustainability strategies, 2) compare Intel with other similar companies, and 3) address the criticism aimed towards Intel's claim to be Ioo percent conflict free. However, in order to develop future strategies, insights from all these previous assignments will be needed, and it is impossible to find good arguments for such strategies without discussing findings from the previous three assignments.

In this course we also create spaces for dialogue between students and corporate representatives. We have had corporate representatives who came to class and commented on the students' solutions to a case. This led to an interesting collaborative experience as the corporate representatives often brought up aspects not covered in the case studies and sometimes aspects that were triggered by the students' analyses. It would be interesting to complement this with dialogues with other stakeholders.

\section{CONCLUDING DISCUSSION}

In this paper we have emphasized the importance of addressing sustainability issues in management education. The case-based method, understood as using ready-made case narratives produced by institutions such as Harvard Business School, is an important pedagogical method within management education because of its aim to analyze more or less real problems, make decisions and take action, but the method has been criticized for being too action oriented (Figueiró \& Raufflet, 20I5; Bridgman et al., 20I6, Chetkovich \& Kirp, 200I; Collinson \& Tourish, 20I5; Liang $\&$ Wang, 2004; Mintzberg, 2004). By explicitly promoting critical thinking and integrating it into the case-based method, we maintain that this method can cater to the twin demands of education for sustainability: critical thinking and action orientation.

In addition to the recommendations in earlier literature to create new cases (Bridgman et al., 2016; Contardo \& Wensley, 2004; Podolny, 2009) or improve classroom practice (Currie \& Tempest, 2008; Rippin et al., 2002), we have provided four hacks for furthering critical thinking in existing cases, namely: (I) exploring synergies and conflicts; (2) expanding empirical knowledge; (3) shifting perspective; and (4) creating spaces for dialogue. While the hacks are all built on previous empirical and conceptual research on critical thinking within ESD, we have not yet assessed qualitatively or quantitatively whether or not the level of critical thinking among students in the course has increased, and this kind of assessment should be seen as an important task for future research. Apart from that, future research could suggest and evaluate other forms of hacks that could complement (and indeed critique) the four that we have presented.

One might also problematize the approach applied in the course Managing sustainability in global industrial companies to focus on large, multinational corporations. There is an emerging strand of literature arguing that rather than focusing on incumbent companies (Binder \& Belz, 20I5), it is better to follow new entrepreneurial initiatives and smaller companies who are already developing a mindset and business model aligned with sustainability goals (Fors \& Lennerfors, 2019). Still, it is plausible that the power of multinational corporations will still be upheld in the near future and, therefore, one should not neglect to pay attention to such companies' managers' roles in facilitating or hindering the advancement towards a more sustainable society.

Another way to problematize our suggestion is that it requires some critical thinking and effort on the part of the educator to hack cases. However, an easy way to start hacking could, for example, be to instruct the students to look for materials and perspectives that go beyond what is written in the case study while working on a case. For the next course round the educator will have received some good ideas from the previous students that could be reviewed and 
implemented. There might be a risk that the workload of working on cases will increase due to the additional materials, perspectives and instructions given. The educator must therefore consider this additional workload when designing education based on hacked cases. However, we believe that the more important implication for students is that they become practically aware that a description in a case (or any other material, for that matter) is never complete, and that there is always a need to go beyond it and probe deeply (Mintzberg, 2004).

Although we are not aware of any papers that discuss the practice of hacking cases, we believe that this is done at various educational institutions. However, such case hacks do not spread to other courses at other educational institutions. Practically, to assist solving this problem, we envisage that a collaborative platform with case hacks which can be used by educators worldwide could be designed. This would enable the sharing of ways in which different teachers have hacked cases in order to promote critical thinking for sustainability. Such a platform could be a living commentary and productive critique existing alongside the constant production of new business cases.

In the paper we have illustrated our hacks by focusing on cases that are already related to sustainability management. However, we believe that our approach can also be used to incorporate a sustainability perspective grounded in critical thinking to cases that at first sight seem to have no relation to sustainability, within managerial domains such as strategy, marketing, operations management, and finance. In such cases, the first hack would urge students to explore synergies and conflicts between values that might be downplayed in the case, and thus to understand how a certain action leads to effects both related to economic sustainability (which the majority of cases focus on) as well as social and environmental sustainability. The second hack would encourage students to look for additional sustainability-related information about the case. The third hack would shift the perspective from the focal company to the perspective of various stakeholders (including those stakeholders who are not given any space in the case description), and the fourth hack would similarly create spaces for dialogues among students, but also between students and stakeholders. Thereby, our hacks could be used to integrate a sustainability perspective grounded in critical thinking across the curriculum in management education.

Looking from a broader perspective, we have opted for a reform of the case-based method rather than a complete revolution of the management curriculum in order to educate for sustainability. Therefore, our approach represents something similar to a bolt-on or built-in approach to sustainability education, according to the typology of Thomas (2009). Although it would perhaps be preferable to completely reform not only management education, but all forms of education to be more in line with the current pressing sustainability challenges, we hold that given the institutional rigidities built into any ongoing educational program, our approach might be more feasible, at least in the short run.

\section{ACKNOWLEDGEMENTS}

We would like to thank Isabelle Giraudou at the University of Tokyo, who has contributed to the development of this paper through continuous discussions while teaching the course Managing sustainability in global industrial companies together. We would also like to thank STINT - the Swedish Foundation for International Cooperation in Research and Higher Education, and Riksbankens Jubileumsfond for financial support for the project "Sweden-Japan I50: internationalizing university education through innovative co-teaching platforms", of which the co-teaching collaboration between Uppsala University and the University of Tokyo 
was a part. An early version of the paper was presented by Thomas Taro Lennerfors at the University of Tokyo Global FD Initiative symposium Frontiers in Higher Education: Diversifying and Transforming Teaching, 29 March 2019.

\section{AUTHOR PRESENTATION}

Thomas Taro Lennerfors is a Professor of Industrial Engineering and Management at Uppsala University. He researches and teaches about the ethics and philosophy of organization and technology. Currently, he is working on a range of papers about ethics and sustainability education primarily for management and engineering students.

Per Fors is a postdoctoral scholar at the Department of Civil and Industrial Engineering at Uppsala University. His main research interests are topics related to technology (mainly ICT/ AI), sustainability, ethics and pedagogy, and he mainly teaches engineering students ethics, sustainability and project management. Per is currently involved in several international research projects related to the topics mentioned above.

Jonathan R. Woodward is a Professor in the Graduate School of Arts and Sciences at the University of Tokyo. His primary area of teaching is chemistry, and his pedagogical interests lie in problem and guided enquiry-based learning and interdisciplinary approaches. His research in the field of biophysics focuses on the magnetosensitivity of chemical and biological processes.

\section{REFERENCES}

Achbar, M., Simpson, B., Achbar, M., \& Abbott, J. (2003). The Corporation [Motion picture]. Canada: Big Picture Media Corporation.

Audebrand, L. K. (2010). Sustainability in strategic management education: The quest for new root metaphors. Academy of Management Learning \& Education, 9(3), 413-428.

Bailin, S., Case, R., Coombs, J. R., \& Daniels, L. B. (1999). Conceptualizing critical thinking. Journal of Curriculum Studies, 31(3), 285-302.

Barnes, L. (1994). Teaching and the case method: Text, cases, and readings. Boston, Mass.: Harvard Business Press.

Binder, J. K., \& Belz, F.-M. (2015). Sustainable entrepreneurship: What it is. In P. Kyrö (Ed.), Handbook of Entrepreneurship and Sustainable Development Research (pp. 30-71). Cheltenham: Edward Elgar Publishing.

Bridgman, T. (2010). Beyond the manager's moral dilemma: Rethinking the 'ideal type' business ethics case. Journal of Business Ethics, 94, 311-322.

Bridgman, T. Cummings, S. \& McLaughlin, C. (2016). Restating the case: How revisiting the development of the case method can help us think differently about the future of the business school. Academy of Management Learning \& Education, 15(4), 724-741.

Chetkovich, C., \& Kirp, D. L. (2001). Cases and controversies: How novitiates are trained to be masters of the public policy universe. Journal of Policy Analysis and Management, 20, 282-314.

Chia, R. (2005). The aim of management education: Reflections on Mintzberg's Managers not MBAs. Organization, 26, 1090-1092.

Collinson, D., \& Tourish, D. (2015). Teaching leadership critically: New directions for leadership pedagogy. Academy of Management Learning \& Education, 14, 576-594.

Contardo, I., \& Wensley, R. (2004). The Harvard Business School story: Avoiding knowledge by being relevant. Organization, 11, 211-231.

Cottrell, S. (2017). Critical thinking skills: Effective analysis, argument and reflection. London: Palgrave. Macmillan International Higher Education.

Crane, A., Palazzo, G., Spence, L. J., \& Matten, D. (2014). Contesting the value of "creating shared value." California Management Review, 56(2), 130-153. 


\section{Thomas Taro Lennerfors et al.}

Currie, G., \& Tempest, S. (2008). Moving towards reflexive use of teaching cases. International Journal of Management Education, 7: 41-50.

Diochon, P. F., Raufflet, E. \& Mills, A. J. (Eds.) (2013). The Dark Side 2: Critical cases on the downside of business. Sheffield: Greenleaf Publishing.

Figueiró, P. S., \& Raufflet, E. (2015). Sustainability in higher education: A systematic review with focus on management education. Journal of Cleaner Production, 106, 22-33.

Fors, P. (2019). Problematizing Sustainable ICT. Doctoral thesis. Uppsala: Act auniversitatis upsaliensis.

Fors, P., \& Lennerfors, T. T. (2019). The individual-care nexus: A theory of entrepreneurial care for sustainable entrepreneurship. Sustainability, 11(18), 4904.

Giraudou, I. J., Lennerfors, T. T., \& Woodward, J. R. (2018). Shouldn't we expect more from case-based learning? The transformative potential of multidisciplinary frameworks in sustainability education. Transformative Dialogues: Teaching \& Learning Journal, 11(3): 1-5.

Haigh, M. (2016). Fostering deeper critical inquiry with causal layered analysis. Journal of Geography in Higher Education, 40(2), 164-181.

Hasslöf, H., \& Malmberg, C. (2015). Critical thinking as room for subjectification in Education for Sustainable Development. Environmental Education Research, 21(2), 239-255.

Hickel, J. (2019). The contradiction of the sustainable development goals: Growth versus ecology on a finite planet. Sustainable Development, 27(5): 873-884.

Hoffman, A. (2015). Intel: Undermining the conflict mineral industry. Harvard Business Case. Retrieved from https://store.hbr.org/product/intel-undermining-the-conflict-mineral-industry/W94C11

Holfelder, A. K. (2019). Towards a sustainable future with education? Sustainability Science, 14(4), 943-952.

Hornborg, A. (2001). The power of the machine: Global inequalities of economy, technology, and environment. AltaMira Press.

Knutsson, B. (2018). Green Machines? Destabilizing Discourse in Technology Education for Sustainable Development. Critical Education, 9(3), 1-18.

Komasinski, A., \& Ishimura, G. (2017). Critical thinking and normative competencies for sustainability science education. Journal of Higher Education and Lifelong Learning, 24, 21-37.

Kramer, M. R., \& Porter, M. (2011). Creating shared value. Harvard Business Review, 89(1/2), 62-77.

Lennerfors, T. T., Fors, P., \& van Rooijen, J. (2015). ICT and environmental sustainability in a changing society: The view of ecological World Systems Theory. Information Technology and People, 28(4), 758-774.

Lennerfors, T. T. (2019). Ethics in engineering. Lund: Studentlitteratur.

Liang, N., \& Wang, J. (2004). Implicit mental models in teaching cases: An empirical study of popular MBA cases in the United States and China. Academy of Management Learning \& Education, 3, 397-413.

MacLellan, L. (2018). The problem with the Harvard Business School case study method. Quartz at Work. Available at: https://qz.com/work/1385066/the-problem-with-harvard-business-school-case-studies/.

Maniates, M. (2017). Suddenly more than academic: Higher education for a post-growth world. In The Worldwatch Institute (Eds.), Earth Ed (pp. 193-206). Washington, DC: Island Press/Center for Resource Economics.

Mason, M. (2007). Critical thinking and learning. Educational Philosophy and Theory, 39(4), 339-349.

Mesny, A. (2013). Taking stock of the century-long utilization of the case method in management education. Canadian Journal of Administrative Sciences/Revue Canadienne Des Sciences De l'Administration, 30(1), 56-66.

Miller, K., \& West, V. (2018). Creative criticality in the meenah neenah Cultural Arts Program. In M. A. Hunter, A. Aprill, A. Hill, \& S. Emery (Eds.), Education, arts and sustainability - Emerging practice for a changing world (pp. 47-60). Singapore: Springer.

Mintzberg, H. (2004). Managers not MBAs: A hard look at the soft practice of managing and management development. San Francisco: Barrett-Koehler.

Montiel, I., Antolin-Lopez, R., \& Gallo, P. J. (2018). Emotions and sustainability: A literary genre-based framework for environmental sustainability management education. Academy of Management Learning \& Education, 17(2), 155-183.

Mulnix, J. W. (2012). Thinking critically about critical thinking. Educational Philosophy and Theory, 44(5), $464-479$. 
Nilson, C. (2011). Teachers' and mothers' perceptions of using creative arts to develop children's potential for critical thinking. The International Journal of Arts Education, 7(1), 1-16.

Onuki, M., \& Mino, T. (2009). Sustainability education and a new master's degree, the Master of Sustainability Science: The Graduate Program in Sustainability Science (GPSS) at the University of Tokyo. Sustainability Science, 4(1), 55.

Osberg, D., \& Biesta, G. (2010). The end/s of education: Complexity and the conundrum of the inclusive educational curriculum. International Journal of Inclusive Education, 14(6), 593-607.

Paine, L. S., Hsieh, N., \& Adamsons, L. (2013). Governance and sustainability at Nike (A). Harvard Business Case. Retreived from https://www.hbs.edu/faculty/Pages/item.aspx?num=44895

Paul, R. (1981). Teaching critical thinking in the "strong" sense: A focus on self-deception, world views, and a dialectical mode of analysis. Informal Logic, 4(2), 2-7.

Paul, R., \& Elder, L. (2007). Critical thinking: The art of Socratic questioning. Journal of Developmental Education, 31(1), 34-35.

Podolny, J. M. (2009). The buck stops (and starts) at business school. Harvard Business Review, 87(6), 62-67.

Price, S. M., \& Hatcher, T. G. (2008). Developing Better Problem Solvers: A Proposal for Problem-Based Learning in Executive Professional Development Programs. Working Paper. Retreived from https://www.ufhrd. co.uk/wordpress/wp-content/uploads/2008/06/pric-53-wp.pdf

Quelch, J. A., \& Rodriguez, M. L. (2014). Royal Caribbean Cruises Ltd.: Safety, Environment, and Health. HBS. Harvard Business Case. Retreived from https://www.hbs.edu/faculty/Pages/item.aspx? num $=46080$

Raufflet, E., \& Mills, A. J. (Eds.). (2009). The Dark Side: Critical cases on the downside of business. Sheffield: Greenleaf Publishing.

Reficco, E., \&Jaén, M. H. (2015). Case method use in shaping well-rounded Latin American MBAs. Journal of Business Research, 68(12), 2540-2551.

Rippin, A., Booth, C., Bowie, S., \& Jordan, J. (2002). A complex case: Using the case study method to explore uncertainty and ambiguity in undergraduate business education. Teaching in Higher Education, 7(4), 429-441.

Sauerbronn, F. F., Diochon, P. F., Raufflet, E. \& Mills, A. J. (Eds.) (2018). The Dark Side 3: Critical cases on the downside of business. New York: Routledge.

Sharen, C. M. \& McGowan, R. A. (2019). Invisible or clichéd: How are women represented in business cases? Journal of Management Education, 43(2), 129-173.

Siller, T. J. (2001). Sustainability and critical thinking in civil engineering curriculum. Journal of Professional Issues in Engineering Education \& Practice, 127(3), 104-108.

Sprain, L., \& Timpson, W. M. (2012). Pedagogy for sustainability science: Case-based approaches for interdisciplinary instruction. Environmental communication: A Journal of Nature and Culture, 6(4), 532-550.

Starkey, K., \& Tempest, S. (2009). The winter of our discontent: The design challenge for business schools. Academy of Management Learning \& Education, 8, 576-586.

Starkey, K., \& Tiratsoo, N. (2007). The business school and the bottom line. Cambridge: Cambridge University Press.

Straková, Z., \& Cimermanová, I. (2018). Critical thinking development-A necessary step in higher education transformation towards sustainability. Sustainability, 10(10), 3366.

Thomas, I. (2009). Critical thinking, transformative learning, sustainable education, and problem-based learning in universities. Journal of Transformative Education, 7(3), 245-264.

UNESCO. (2017). Education for sustainable development goals: Learning objectives. Education for Sustainable Development. The Global Education 2030 Agenda. United Nations Educational, Scientific and Cultural Organization.

Van Poeck, K. \& Östman, L. (2017). Creating space for 'the political' in environmental and sustainability education practice: A political move analysis of educators' actions. Environmental Education Research, 24(8), 1406-1423.

Wals, A. E. J., \& Jickling, B. (2002). "Sustainability” in higher education. International Journal of Sustainability in Higher Education, 3(3), 221-232.

Zoller, U. (2015). Based transformative science/STEM/STES/STESEP education for "sustainability thinking": From teaching to "know" to learning to "think." Sustainability, 7(4), 4474-4491. 